\title{
Recent advances in understanding the role of leptin in energy
}

\section{homeostasis [version 1; peer review: 2 approved]}

\author{
Heike Münzberg, Prachi Singh, Steven B. Heymsfield, Sangho Yu, \\ Christopher D. Morrison
}

Pennington Biomedical Research Center, Louisiana State University System, Louisiana, USA

\section{V1 First published: 27 May 2020, 9(F1000 Faculty Rev):451 \\ https://doi.org/10.12688/f1000research.24260.1}

Latest published: 27 May 2020, 9(F1000 Faculty Rev):451

https://doi.org/10.12688/f1000research.24260.1

\section{Abstract}

The hormone leptin plays a critical role in energy homeostasis, although our overall understanding of acutely changing leptin levels still needs improvement. Several developments allow a fresh look at recent and early data on leptin action. This review highlights select recent publications that are relevant for understanding the role played by dynamic changes in circulating leptin levels. We further discuss the relevance for our current understanding of leptin signaling in central neuronal feeding and energy expenditure circuits and highlight cohesive and discrepant findings that need to be addressed in future studies to understand how leptin couples with physiological adaptations of food intake and energy expenditure.

\section{Keywords}

Food intake, energy expenditure, Arcuate nucleus, dorsomedial hypothalamus, MC4R, POMC, AgRP, neuronal activity, fiber photometry

\section{Open Peer Review \\ Approval Status \\ 1 \\ 2 \\ version 1 \\ 27 May 2020 \\ Faculty Reviews are review articles written by the prestigious Members of Faculty Opinions. The articles are commissioned and peer reviewed before publication to ensure that the final, published version is comprehensive and accessible. The reviewers who approved the final version are listed with their names and affiliations.}

1. Greg M Anderson, University of Otago,

Dunedin, New Zealand

2. Carol F Elias, University of Michigan, Ann Arbor, USA

Any comments on the article can be found at the end of the article. 
Corresponding author: Heike Münzberg (Heike.Munzberg@pbrc.edu)

Author roles: Münzberg H: Conceptualization, Funding Acquisition, Writing - Original Draft Preparation, Writing - Review \& Editing; Singh P: Writing - Original Draft Preparation, Writing - Review \& Editing; Heymsfield SB: Writing - Original Draft Preparation, Writing Review \& Editing; Yu S: Writing - Original Draft Preparation, Writing - Review \& Editing; Morrison CD: Writing - Original Draft Preparation, Writing - Review \& Editing

Competing interests: Steven B. Heymsfield is on the Medical Advisory Board of Medifast Corporation. Heike Münzberg, Prachi Singh, Sangho Yu, and Christopher D. Morrison declare that they have no competing interests.

Grant information: This work was supported by the National Institutes of Health Grants R01 DK092587 and OT2OD023864 (SPARC) to H.M.

The funders had no role in study design, data collection and analysis, decision to publish, or preparation of the manuscript.

Copyright: @ 2020 Münzberg $\mathrm{H}$ et al. This is an open access article distributed under the terms of the Creative Commons Attribution License, which permits unrestricted use, distribution, and reproduction in any medium, provided the original work is properly cited.

How to cite this article: Münzberg $H$, Singh $P$, Heymsfield SB et al. Recent advances in understanding the role of leptin in energy homeostasis [version 1; peer review: 2 approved] F1000Research 2020, 9(F1000 Faculty Rev):451

https://doi.org/10.12688/f1000research.24260.1

First published: 27 May 2020, 9(F1000 Faculty Rev):451 https://doi.org/10.12688/f1000research.24260.1 


\section{Introduction}

The adipose tissue-derived hormone leptin plays a critical role in whole body energy homeostasis: lack of functional leptin or leptin receptors (Lepr) results in severe and early onset obesity in rodents and humans, while leptin replacement in leptin-deficient rodents and humans fully recovers energy homeostasis ${ }^{1,2}$. Leptin mediates its effect via the central nervous system, and neuron-specific re-expression of Lepr in whole body Lepr-deficient mice is sufficient for full recovery of all known physiological effects of leptin and Lepr deficiency ${ }^{3}$. Nevertheless, documented peripheral leptin action might support several aspects of leptin functions ${ }^{4-6}$.

A more confusing literature addresses leptin's role in normal physiology and the relevance of the observed dynamic changes in circulating leptin levels. Long-term circulating leptin levels are positively correlated with adiposity, but short-term circadian changes ${ }^{7,8}$ or acute changes (hours) in response to physiological challenges such as fasting/refeeding ${ }^{9,10}$, cold exposure ${ }^{11}$, sleep restriction ${ }^{12-14}$, hypoxia ${ }^{15,16}$, methionine restriction ${ }^{17,18}$, or type 1 diabetes $^{9}$ are known.

Circulating leptin levels reflect leptin sensitivity with regard to the ability of exogenous applied leptin to increase signaling pathways and physiological function. A drop in leptin levels sensitizes while high leptin levels blunt leptin signaling and function, also known as leptin resistance. This resistance is mediated via negative feedback signals in the Lepr signaling cascade that build up with elevated leptin levels (or diminish with low leptin levels) and suppress leptin signaling efficiency (for detailed reviews, see 19-22).

Yet there is no consensus on how changes in endogenous leptin levels are relevant for body weight homeostasis. High leptin levels in obesity are particularly puzzling because leptin seems to be unable to reduce food intake and prevent obesity, despite appropriate induction of many early leptin signaling events ${ }^{23}$. Some data even suggest that hyperleptinemia may prevent further detrimental effects on food intake, body weight, and glucose homeostasis ${ }^{24-26}$. Weight loss that is achieved with dieting and exercise is "sensed" as negative energy balance and the associated drop in leptin levels enables physiological adaptations (e.g. decreased energy expenditure and increased hunger) geared to favor weight regain. These adaptations are reversed by leptin treatment, which improves weight loss maintenance in mice and humans ${ }^{27-29}$. Conversely, the dramatic weight loss achieved with bariatric surgery is surprisingly not "sensed" as an energy need state, compared to weight-matched control animals, despite similarly decreased leptin levels ${ }^{30}$. The lack of adaptive responses enables the stunning long-term weight loss and improved glucose homeostasis following bariatric surgery. A critical future task is to understand how dynamic changes in leptin levels couple with (or uncouple from) physiological adaptations of food intake and energy expenditure.

This review will highlight some recent publications that are relevant for the role of dynamic changes in circulating leptin levels in health and disease. We further discuss their relevance for our current understanding of leptin signaling in central feeding and energy expenditure circuits and highlight cohesive and discrepant findings that need to be addressed in future studies to understand how leptin couples with physiological adaptations.

\section{Regulation of circulating leptin levels and functional importance}

Leptin levels are regulated by a feedback signal according to the body's energy availability ${ }^{31}$. Inhibition of leptin gene expression is generally associated with a negative energy state or increased energy need states, such as fasting ${ }^{11}$, cold exposure $^{10}$, methionine restriction ${ }^{17,18}$, type 1 diabetes ${ }^{9,32}$, or exercise $^{33}$. Neuroendocrine adaptations to these physiological conditions, such as fasting (e.g. increased corticosterone and ACTH, low thyroid hormone), can be reversed or significantly blunted when leptin levels are restored ${ }^{27,29}$. Conversely, increased leptin gene expression is associated with a positive energy state, and circulating leptin correlates positively with adipose tissue mass ${ }^{34}$.

However, the key regulatory processes that control leptin gene expression remain unclear. Only recently, a novel PPAR $\gamma /$ RXR binding site was identified within one of the leptin promoter elements that also restricts leptin gene expression to adipose tissue. These data suggested the binding of PPAR $\gamma$ with one or more unidentified factor(s) that together enable the suppression of leptin gene expression and adipose tissue lipolysis may likely induce this factor ${ }^{35}$. Adipose tissue lipolysis is a hallmark of energy need states and depends on $\beta 3$-adrenergic receptor signaling. Similarly, leptin gene expression is suppressed by increased sympathetic tone via $\beta 3$-adrenergic receptors ${ }^{10,11,36-38}$.

Recent work also found that low leptin levels are required to increase the HPA axis ${ }^{9,32}$, even though this view is debated ${ }^{39}$. This mechanism is intriguing, as increased glucocorticoids are associated with many hypoleptinemic states like fasting, sleep deprivation, and cold exposure ${ }^{9,12,40}$. This emerging role of glucocorticoids to drive hunger and food intake in response to decreased leptin levels ${ }^{9,41,42}$ might be critical to understand the coupling of leptin levels with physiological adaptations of feeding and energy expenditure. However, the mechanisms through which central circuits regulate leptin gene expression are unclear. Such circuits will likely control sympathetic tone in adipose tissue and have been described for brown adipose tissue $(\mathrm{BAT})^{43,44}$ and are likely distinct from white adipose tissue (WAT) based on the anatomical dissociation of pre- and post-ganglionic inputs to BAT and WAT (44 and Huesing et al. unpublished data). Also, some studies suggested distinct contribution of subsets of arcuate nucleus (ARC) neurons for differential sympathetic tone to adipose tissues, substrate fluxes, and suppression of leptin gene expression ${ }^{45-47}$.

\section{Central leptin action and energy homeostasis}

Central hypothalamic circuits are critical to mediate leptin signaling and promote energy homeostasis via modulation of food intake and energy expenditure. Within the ARC, two 
conversely acting neuronal populations are well characterized for their interaction with leptin: anorexigenic and energy expenditure-inducing pro-opiomelanocortin (POMC) neurons and orexigenic and energy expenditure-suppressing agouti-related peptide (AgRP) neurons. POMC-derived peptides have stimulatory and AgRP inhibitory effects on melanocortin-4 receptors $(\mathrm{MC} 4 \mathrm{R})^{48,49}$, and their converse actions may involve several levels (e.g. antagonism, Gi/Gs signaling) ${ }^{50}$. Changes in neuronal activation of POMC and AgRP neurons are critical for sensing energy availability states, and both populations are responsive to a range of orexigenic and anorexigenic signals ${ }^{51}$. AgRP neurons are activated during energy need states (low leptin levels), while POMC neurons are activated in energy replete or overfeeding states (normal/high leptin levels). Initially, this correlation was histologically shown by expression of the early response gene $c F o s$, as well as POMC and AgRP, which correlated well with neuronal activation ${ }^{48,52,53}$; recent studies confirmed this with fiber photometry, which allowed real-time observation of neuronal activity changes ${ }^{54,55}$. AgRP neuronal activation studies further indicated that feeding behavior dissociates into rapid (within minutes) and slow (within days) feeding events ${ }^{56-58}$. Generally, AgRP neuron-induced rapid feeding events require the co-expressed neuropeptide NPY ${ }^{56,59,60}$, while slow feeding events require AgRP or POMC signaling via

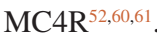

The temporal responses of AgRP and POMC neurons are particularly relevant for leptin signaling. Recent data demonstrated a gradual and slow leptin action in POMC and AgRP neurons, while rapid activity changes are mediated by many gut peptides, but not leptin ${ }^{51}$. The slow kinetics of leptin action are consistent with transcriptional events and in line with many early studies demonstrating that leptin induces POMC mRNA and suppresses AgRP mRNA (reviewed in 48). Importantly, the weight loss achieved with bariatric surgery suppresses leptin levels similar to what is seen in weight-matched animals, but the increased AgRP mRNA was absent with bariatric surgery, unlike in weight-matched animals ${ }^{62}$. Similarly, MC4Rdeficient and leptin-deficient mice are resistant or show blunted weight loss to bariatric surgery ${ }^{63,64}$, further pointing to an important role for leptin $>\mathrm{MC} 4 \mathrm{R}$ signaling to mediate this effect, even though sleeve gastrectomy-mediated weight loss did not depend on MC4R signaling ${ }^{65}$.

Thus, a better understanding of how leptin modulation of MC4R signaling integrates into neuronal circuits that regulate feeding and energy expenditure would be important to target unwanted coupling of low leptin levels with physiological adaptations in obese individuals as well as beneficial uncoupling in bariatric surgery patients.

\section{Energy homeostasis and food intake}

Leptin levels are critical to regain energy homeostasis following fasting or overfeeding. Leptin acts via POMC and AgRP neurons to suppress MC4R neurons in the paraventricular hypothalamus $(\mathrm{PVH})^{29,66-68}$, which can be considered the critical circuit to couple changes in leptin levels with food intake adaptations (Figure 1A). However, fasting-induced hyperphagia or overfeeding-induced hypophagia cannot be explained by acute neuronal activation states of POMC and AgRP neurons. The fasting-induced activity patterns in POMC and AgRP neurons (POMC activity $\downarrow$, AgRP activity $\uparrow$ ) normalize within seconds of food availability ${ }^{55}$, so that the observed long-lasting hyperphagia must be mediated by additional mechanisms.

Low leptin causes chronic cFos expression in AgRP neurons and is thought to reflect chronic activation of AgRP neurons. Thus, leptin-deficient $o b / o b$ mice might not respond properly to refeeding and fail to normalize AgRP neuronal activity. Surprisingly, POMC and AgRP neurons in $o b / o b$ mice remain fully responsive ${ }^{51}$, concluding that acute activity changes are not the main cause for obesity in $o b / o b$ mice. Instead, these data refocus our attention to earlier studies, demonstrating the importance of transcriptional changes in AgRP and POMC mRNA for weight gain and obesity ${ }^{69}$. Similarly, long-term feeding and AgRP expression can be mediated independent of neuronal activity and require at least one additional transcription factor ${ }^{52}$, even though it is currently unclear if slow-acting leptin, rapid-acting gut peptides, or associated factors like corticosterone may have the same or distinct impact on melanocortin gene expression.

We speculate that the duration of fasting or overfeeding shifts the ratio of POMC-derived peptides (energy surplus) versus AgRP peptide (energy need) and has prolonged effects on MC4R signaling. Dependent on the stability of mRNA and peptides, this system could be active despite normalized neuronal activity and explains why physiological adaptations to favor weight gain are long-lasting in contrast to the rapid neuronal activation changes. Indeed, the duration of AgRP neuronal activity correlates with the amount of food ingested ${ }^{55}$, but this study did not specifically study long-term feeding. AgRP is sufficient to mediate long-term feeding responses ${ }^{58,60}$, even though rapid changes in feeding via NPY may contribute to overall food intake. Conversely, rapid normalization of AgRP and POMC neuronal activity and leptin levels would promote normalization of POMC/AgRP ratios over time to reinstate homeostasis (Figure 2).

In line with this concept, lack of functional POMC expression (causing unopposed AgRP action) causes severe obesity with increased food intake and suppressed energy expenditure ${ }^{70}$. Conversely, prolonged treatment with an MC4R agonist was able to promote lasting weight loss in Lepr-deficient patients ${ }^{71}$. Thus, re-establishing the energy surplus signal from POMC neurons seems to be a key component for long-lasting weight loss. Similarly, POMC neurons require chronic (24 hours) optogenetic activation to suppress feeding, which was blocked in Agouti mice with chronic MC4R inactivation ${ }^{61}$ and is consistent with a slow buildup of POMC-derived peptides at MC4R neurons. Earlier studies also showed that elevated POMC expression and MC4R signaling are important mediators of the homeostatic adaptations to overfeeding and these adaptations were prevented by blocking MC4R with an antagonist ${ }^{66}$ or in leptin signaling-deficient animals ${ }^{67}$. These observations would explain why bariatric surgery is ineffective in MC4R knockout or $o b / o b$ mice and suggests a prominent role for MC4R signaling in the full beneficial effects of bariatric surgery. 


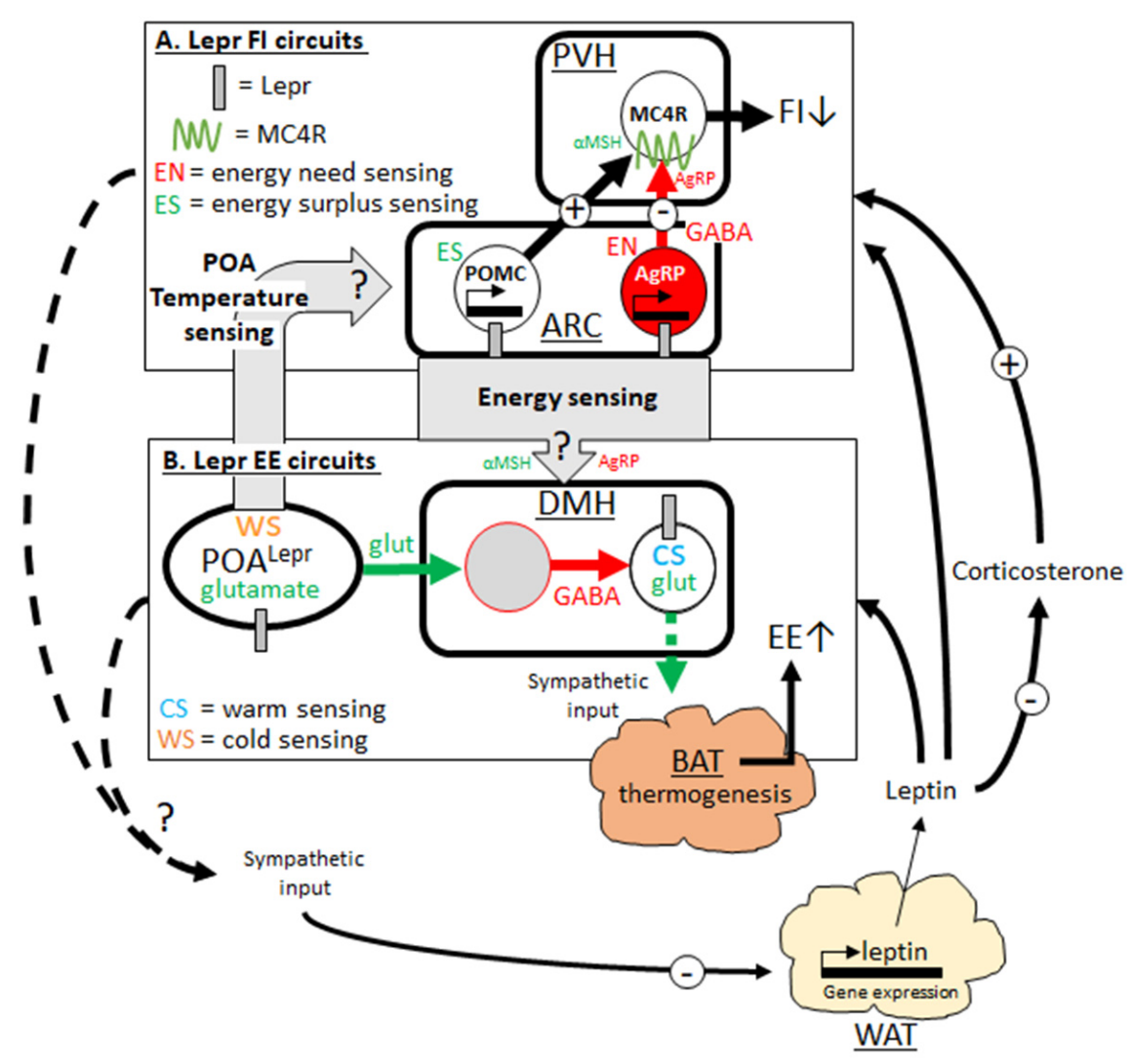

Figure 1. Lepr-centric scheme of feeding and energy expenditure circuits. Changing leptin levels act on food intake (FI, $1 \mathrm{~A})$ and energy expenditure $(\mathrm{EE}, 1 \mathrm{~B})$ via divergent MC4R neurons in the paraventricular hypothalamus $(\mathrm{PVH})^{68}$ and dorsomedial hypothalamus $(\mathrm{DMH})^{72}$ respectively. Temperature sensing via the preoptic area (POA) and energy sensing via the arcuate nucleus (ARC) are both associated with changing leptin levels and require physiological adaptations of $\mathrm{FI}$ and $\mathrm{EE}$. Both sensory inputs are likely to integrate via the same $\mathrm{FI}$ and EE circuits. Recent data further suggest that low leptin levels enable agouti-related peptide (AgRP)-induced feeding via an increased HPA axis $^{9}$, raising awareness for a tight interaction of peripheral and central signaling systems. Dynamic changes in leptin levels are a critical part in these FI and EE circuits, and the central feedback mechanisms for this important link are unclear. $\alpha$-MSH, $\alpha$-melanocyte-stimulating hormone; BAT, brown adipose tissue; GABA, gamma aminobutyric acid; Lepr, leptin receptor; MC4R, melanocortin-4 receptor; POMC, proopiomelanocortin; WAT, white adipose tissue.

Furthermore, the role of leptin signaling in ARC neurons has been confusing following initial work which removed Lepr from POMC, AgRP, or both neurons ${ }^{73,74}$. The observed mild effects on body weight compared to whole body Lepr-deficient $d b / d b$ mice led to a shift away from an ARC-centric view of leptin action, and several non-ARC Lepr neurons were discovered with similarly mild contributions to whole body leptin function ${ }^{75}$. However, a recent study used CRISPR technology for an acute and AgRP-specific Lepr deletion ${ }^{42}$ and clarified that AgRP-specific Lepr deletion explained $\sim 80 \%$ of the obese phenotype in $d b / d b$ mice. This effect was largely independent of direct changes in neuronal activity, again suggesting that transcriptional events (increased AgRP mRNA) may most prominently drive this effect. This study also deleted Lepr from POMC neurons with only mild effects on body weight and food intake, even though a thorough investigation of homeostatic adaptations in response to overfeeding was not performed ${ }^{42}$.
Together, these studies again reinforce the importance of ARC Lepr neurons in maintaining body weight homeostasis, yet the relative contribution of POMC versus AgRP neurons needs re-clarification, specifically since recent studies show a strong bias towards the importance of AgRP versus POMC neurons. New state-of-the-art methods such as fiber photometry to study the long-term effects of leptin and melanocortin signaling on neural activity are problematic, since this method is mainly used to observe acute activity changes. However, long-term activity changes were successfully observed in leptin-treated $o b / o b$ mice, even though these responses could not be observed in wild-type mice ${ }^{51}$. A recent fiber photometry study in PVN MC4R feeding neurons surprisingly failed to show feedinginduced activity changes ${ }^{76}$, possibly because only acute responses were evaluated. Thus, future development of experimental paradigms that allow reliable interpretation of long-term effects of leptin and melanocortin signaling on neuronal activity and 


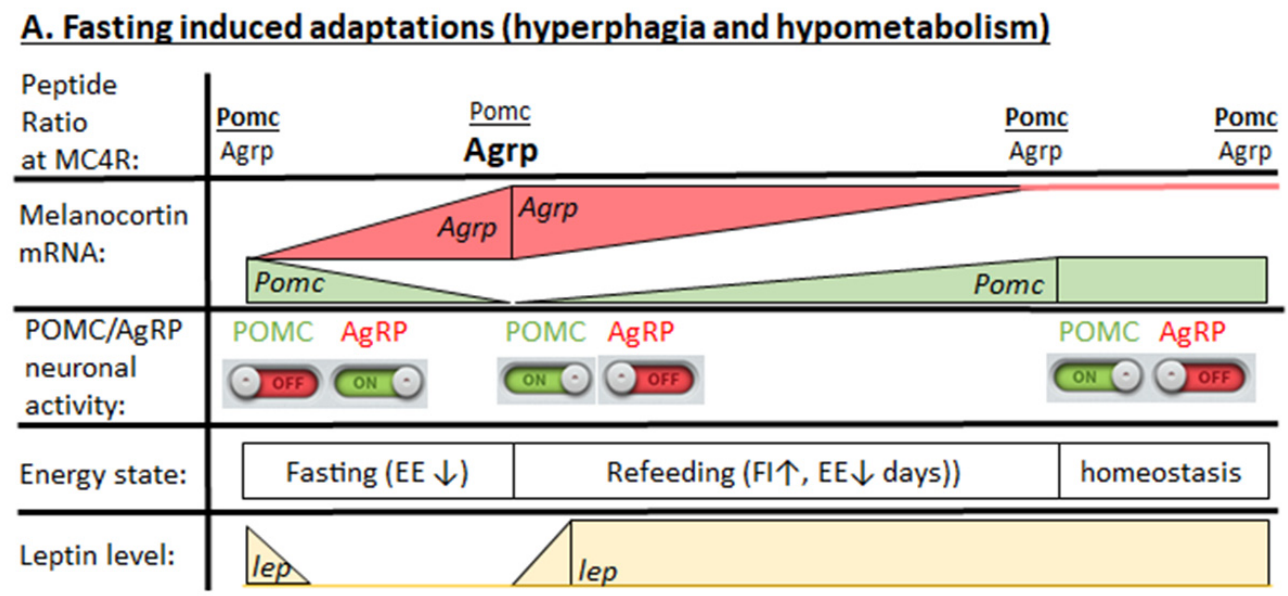

B. Overfeeding induced adaptations (hypophagia and hypometabolism)

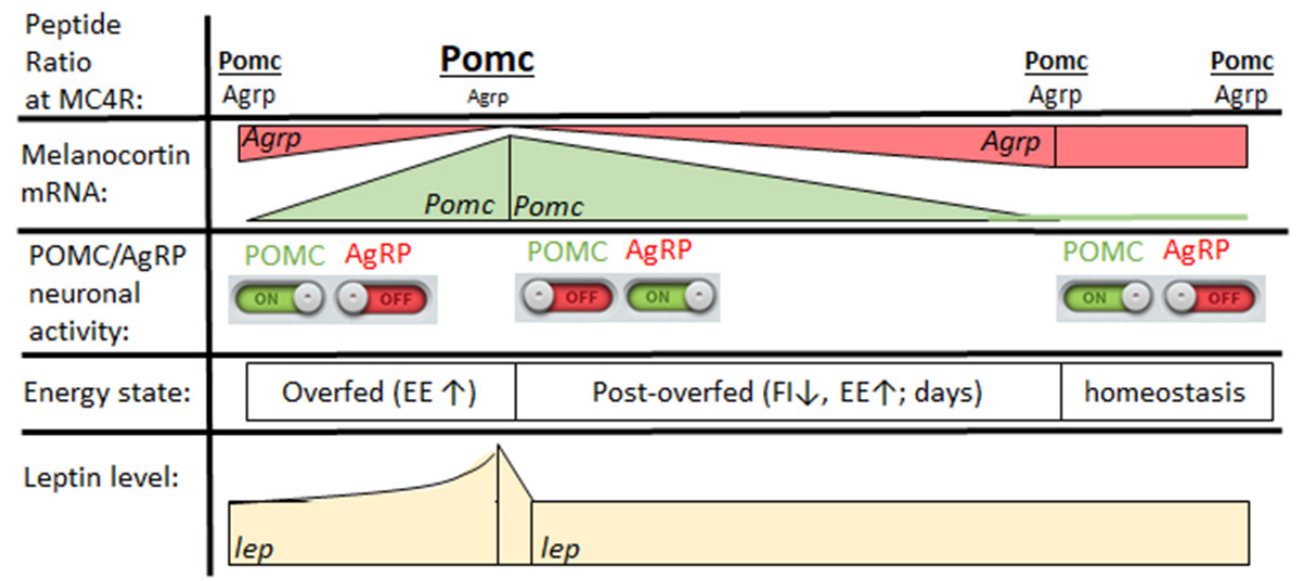

Figure 2. Schematic diagram to explain how acute changes in POMC and AgRP neuronal activity can be dissociated from the dynamic changes in leptin levels and their interaction with POMC and AgRP gene expression and melanocortin peptide ratios to stimulate or inhibit MC4Rs in food intake and energy expenditure circuits. Note, the duration and fold change of leptin mRNA expression as well as release into the serum have not been fully explored, but a full suppression of leptin mRNA within 2 hours has been reported ${ }^{10}$. AgRP, agouti-related peptide; EE, energy expenditure; FI, food intake; POMC, pro-opiomelanocortin; MC4R, melanocortin-4 receptor.

feeding responses is critical to connect new technologies with this important signaling pathway in energy homeostasis.

\section{Energy homeostasis and energy expenditure}

The role of leptin in increasing energy expenditure has been debated ${ }^{77}$ in contrast to the well-accepted anorexigenic leptin actions. Leptin increases the sympathetic tone to BAT, a site of increased energy usage and thus increased energy expenditure ${ }^{78,79}$. However, leptin injections are unable to influence metabolic rate per $s e^{80,81}$. Instead, leptin counteracts the hypometabolism induced by energy need states in both rodents and humans $\mathrm{s}^{27,28,80,82}$. Furthermore, leptin affects thermoregulation, body temperature, and cold sensitivity in mice $^{83-86}$, even though this has not been observed in humans ${ }^{1}$.

Lepr-expressing neurons are part of a thermoregulatory circuit that connects the preoptic area (POA) and dorsomedial hypothalamus/dorsal hypothalamic area (DMH/DHA) to the sympathetic control of $\mathrm{BAT}^{87}$. Lepr neurons in the DMH/DHA explain many leptin functions on energy expenditure and body temperature. DMH/DHA Lepr neurons are activated by cold exposure (cold-sensing neurons) and leptin ${ }^{43,85}$, and activation of DMH/DHA Lepr neurons is sufficient to increase energy expenditure via sympathetic activation of BAT that depends on $\beta 3$-adrenergic signaling. Lepr expression in these neurons is required to prevent hypometabolism and weight gain, and DMH/DHA leptin infusion is sufficient to normalize body temperature and improve body weight in $o b / o b$ mice and obese rats without affecting food intake ${ }^{43,88}$. Together, these observations suggest that DMH/DHA Lepr neurons are important for coupling changes in leptin levels with energy expenditure adaptations (Figure 1B).

Lepr neurons in the POA are a homogenous population of glutamatergic neurons that are activated by warm temperature (warm-sensing neurons), and chemogenetic activation causes a 
robust suppression of energy expenditure ${ }^{89}$. Originally, warmsensing POA neurons were identified as GABAergic neurons, based on the marker glutamate decarboxylase (Gad1/2 aka Gad65/67 $)^{90,91}$. However, detailed single cell profiling of POA neurons clarified its expression in both GABA and glutamatergic neurons and ultimately verified warm-sensing POA neurons as a homogenous glutamatergic cluster with Lepr expression ${ }^{92}$. Warm-sensing POA neurons innervate the DMH and inhibit cold-sensing DMH/DHA neurons ${ }^{43,89,91,93-95}$, likely indirectly via GABAergic interneurons (Figure 1B).

Leptin signaling has no effect on temperature-dependent energy expenditure changes ${ }^{81,96}$, but POA leptin action surprisingly contributed to counteracting weight gain in a state of energy surplus (high-fat diet feeding) and energy expenditure adaptations in an energy need state (fasting-induced hypometabolism $)^{81}$. This suggested that POA Lepr neurons play a role in coupling leptin signaling with energy expenditure adaptations. As noted above, negative and positive energy states are classically controlled by ARC POMC (energy surplus sensing) and AgRP neurons (energy need sensing), including acute changes in neuronal activity as well as transcriptional changes of POMC and AgRP expression. Thus, an interaction of temperature-sensing POA Lepr neurons with energy-sensing mechanisms suggests that both sensory inputs merge into the same circuits. Interestingly, a recent study demonstrated that the MC4R agonist MTII induces energy expenditure exclusively via $\mathrm{DMH} \mathrm{MC}^{\mathrm{R}} \mathrm{R}^{72}$. Importantly, DMH MC4R had no effect on the food intake-suppressing effects of $\mathrm{MTII}^{72}$, which is mediated exclusively by PVN MC4R neurons ${ }^{68}$. Thus, these data further indicate the DMH as the likely integration site for ARC and POA neurons on energy expenditure adaptations (Figure 1B).

Warm-sensing POA neurons also suppress food intake in response to ambient temperature, and activation of warmsensing POA Lepr neurons robustly reduces body weight ${ }^{81,97}$. Interestingly, leptin-deficient mice are unable to suppress their food intake in response to warm ambient temperature, and their food intake is maintained at levels comparable to cold-exposed animals ${ }^{96}$. The hyperphagia in $o b / o b$ mice is caused by the unopposed AgRP action at PVN MC4R neurons and is resistant to acute POMC activation ${ }^{61}$. Thus, we speculated that temperature-induced food intake adaptations also integrate into the same feeding circuit as energy-sensing inputs (PVN MC4R neurons) (Figure 1A).

An integration of temperature and energy sensing via distinct feeding and energy expenditure circuits may further integrate other sensory inputs associated with changes in leptin levels (sleep restriction, hypoxia, protein restriction, etc.), even though integration could also occur downstream to the PVN and DMH within these circuits.

\section{Summary and outlook}

Recent work has identified leptin promoter regions that mediate dynamic changes in leptin levels and predicts binding factors that are activated by lipolysis to suppress leptin levels. We further emphasized the importance of understanding the physiological cause and function of leptin levels in healthy individuals: to understand how we can leverage this system to treat metabolic dysfunctions. We consider the coupling of leptin levels with physiological adaptations of food intake and energy expenditure as critical components to treat metabolic dysfunction because they prevented long-term weight maintenance in obese patients and their uncoupling enables long-term weight loss in bariatric surgery patients. We make the case for an emerging concept that couples leptin signaling with food intake adaptations via PVN MC4R neurons and with energy expenditure adaptations via DMH MC4R neurons. We outline evidence indicating substantial integration of temperature- and energy-sensing adaptations of food intake and energy expenditure across these circuits. These concepts are likely relevant for other non-metabolic leptin functions, such as reproduction, that we did not specifically discuss in this review. Finally, we highlight the need to develop new protocols for current stateof-the-art technologies to accommodate the study of slower kinetics for leptin and melanocortin signaling to ensure future progress in this field.
1. Farooqi IS, Matarese G, Lord GM, et al.: Beneficial effects of leptin on obesity, T cell hyporesponsiveness, and neuroendocrine/metabolic dysfunction of human congenital leptin deficiency. J Clin Invest. 2002; 110(8): 1093-103. PubMed Abstract | Publisher Full Text | Free Full Text

2. Harris RB, Zhou J, Redmann SM, et al:: A leptin dose-response study in obese (ob/ob) and lean (+/?) mice. Endocrinology. 1998; 139(1): 8-19. PubMed Abstract | Publisher Full Text

3. F de Luca C, Kowalski TJ, Zhang Y, et al:: Complete rescue of obesity, diabetes, and infertility in $\mathrm{db} / \mathrm{db}$ mice by neuron-specific LEPR-B transgenes. J Clin Invest. 2005; 115(12): 3484-93.

PubMed Abstract | Publisher Full Text | Free Full Text | F1000 Recommendation

4. Huan JN, Li J, Han Y, et al:: Adipocyte-selective reduction of the leptin receptors induced by antisense RNA leads to increased adiposity, dyslipidemia, and insulin resistance. J Biol Chem. 2003; 278(46): 45638-50. PubMed Abstract | Publisher Full Text
5. $\quad \mathrm{F}$ Wang MY, Orci L, Ravazzola M, et al.: Fat storage in adipocytes requires inactivation of leptin's paracrine activity: implications for treatment of human obesity. Proc Natl Acad Sci U S A. 2005; 102(50): 18011-6. PubMed Abstract | Publisher Full Text | Free Full Text | F1000 Recommendation

6. Tavernier A, Cavin JB, Le Gall M, et al.: Intestinal deletion of leptin signaling alters activity of nutrient transporters and delayed the onset of obesity in mice. FASEB J. 2014; 28(9): 4100-10. PubMed Abstract | Publisher Full Text | Free Full Text

7. Schoeller DA, Cella LK, Sinha MK, et al.: Entrainment of the diurnal rhythm of plasma leptin to meal timing. J Clin Invest. 1997; 100(7): 1882-7. PubMed Abstract | Publisher Full Text | Free Full Text

8. Elimam A, Marcus C: Meal timing, fasting and glucocorticoids interplay in serum leptin concentrations and diurnal profile. Eur J Endocrinol. 2002; 147(2): 181-8. PubMed Abstract | Publisher Full Text 
9. $\quad \mathrm{F}$ Perry RJ, Resch JM, Douglass AM, et al:: Leptin's hunger-suppressing effects are mediated by the hypothalamic-pituitary-adrenocortical axis in rodents. Proc Natl Acad Sci U S A. 2019; 116(27): 13670-9. PubMed Abstract | Publisher Full Text | Free Full Text | F1000 Recommendation

10. Trayhurn P, Thomas ME, Duncan JS, et al.: Effects of fasting and refeeding on ob gene expression in white adipose tissue of lean and obese $(o b / o b)$ mice. FEBS Lett. 1995; 368(3): 488-90.

PubMed Abstract | Publisher Full Text

11. Trayhurn P, Duncan JS, Rayner DV: Acute cold-induced suppression of ob (obese) gene expression in white adipose tissue of mice: mediation by the sympathetic system. Biochem J. 1995; 311(Pt 3): 729-33.

PubMed Abstract | Publisher Full Text | Free Full Text

12. Spiegel $K$, Leproult $R$, L'hermite-Balériaux $M$, et al.: Leptin levels are dependent on sleep duration: relationships with sympathovagal balance, carbohydrate regulation, cortisol, and thyrotropin. J Clin Endocrinol Metab. 2004; 89(11): 5762-71.

PubMed Abstract | Publisher Full Text

13. Omisade A, Buxton OM, Rusak B: Impact of acute sleep restriction on cortisol and leptin levels in young women. Physiol Behav. 2010; 99(5): 651-6. PubMed Abstract | Publisher Full Text

14. Capers PL, Fobian AD, Kaiser KA, et al:: A systematic review and meta-analysis of randomized controlled trials of the impact of sleep duration on adiposity and components of energy balance. Obes Rev. 2015; 16(9): 771-82. PubMed Abstract | Publisher Full Text | Free Full Text

15. Grosfeld A, Zilberfarb V, Turban S, et al.: Hypoxia increases leptin expression in human PAZ6 adipose cells. Diabetologia. 2002; 45(4): 527-30. PubMed Abstract | Publisher Full Text

16. Yang R, Sikka G, Larson J, et al:: Restoring leptin signaling reduces hyperlipidemia and improves vascular stiffness induced by chronic intermittent hypoxia. Am Physiol Heart Circ Physiol. 2011; 300(4): H1467-H1476. PubMed Abstract | Publisher Full Text | Free Full Text

17. Hasek BE, Stewart LK, Henagan TM, et al.: Dietary methionine restriction enhances metabolic flexibility and increases uncoupled respiration in both fed and fasted states. Am J Physiol Regul Integr Comp Physiol. 2010; 299(3): R728-39.

PubMed Abstract | Publisher Full Text | Free Full Text

18. Plaisance EP, Henagan TM, Echlin $\mathrm{H}$, et al:: Role of beta-adrenergic receptors in the hyperphagic and hypermetabolic responses to dietary methionine restriction. Am J Physiol Regul Integr Comp Physiol. 2010; 299(3): R740-R750. PubMed Abstract | Publisher Full Text | Free Full Text

19. Myers MG, Cowley MA, Münzberg H: Mechanisms of leptin action and leptin resistance. Annu Rev Physiol. 2008; 70: 537-56.

PubMed Abstract | Publisher Full Tex

20. Münzberg H: Differential leptin access into the brain--a hierarchical organization of hypothalamic leptin target sites? Physiol Behav. 2008; 94(5): 664-9. PubMed Abstract | Publisher Full Text

21. Myers MG Jr, Leibel RL, Seeley RJ, et al:: Obesity and leptin resistance: distinguishing cause from effect. Trends Endocrinol Metab. 2010; 21(11): 643-51. PubMed Abstract | Publisher Full Text | Free Full Text

22. Myers MG Jr, Heymsfield SB, Haft C, et al:: Challenges and opportunities of defining clinical leptin resistance. Cell Metab. 2012; 15(2): 150-6. PubMed Abstract | Publisher Full Text | Free Full Text

23. F Pan WW, Myers MG: Leptin and the maintenance of elevated body weight. Nat Rev Neurosci. 2018; 19(2): 95-105. PubMed Abstract | Publisher Full Text | F1000 Recommendation

24. Knight ZA, Hannan KS, Greenberg ML, et al.: Hyperleptinemia is required for the development of leptin resistance. PLoS One. 2010; 5(6): e11376. PubMed Abstract | Publisher Full Text | Free Full Text

25. F Dallner OS, Marinis JM, Lu YH, et al.: Dysregulation of a long noncoding RNA reduces leptin leading to a leptin-responsive form of obesity. Nat Med. 2019; 25(3): 507-16.

PubMed Abstract | Publisher Full Text | F1000 Recommendation

26. Münzberg H, Heymsfield SB: New Insights into the Regulation of Leptin Gene Expression. Cell Metab. 2019; 29(5): 1013-4. PubMed Abstract | Publisher Full Text

27. Rosenbaum M, Goldsmith $\mathrm{R}$, Bloomfield $\mathrm{D}$, et al: Low-dose leptin reverses skeletal muscle, autonomic, and neuroendocrine adaptations to maintenance of reduced weight. J Clin Invest. 2005; 115(12): 3579-86. PubMed Abstract | Publisher Full Text | Free Full Text

28. Rosenbaum M, Leibel RL: Adaptive thermogenesis in humans. Int $\mathrm{J}$ Obes (Lond). 2010; 34 Suppl 1(0 1): S47-55.

PubMed Abstract | Publisher Full Text | Free Full Text

29. Ahima RS, Prabakaran D, Mantzoros C, et al:: Role of leptin in the neuroendocrine response to fasting. Nature. 1996; 382 (6588): 250-2. PubMed Abstract | Publisher Full Text

30. Hao Z, Townsend RL, Mumphrey MB, et al.: RYGB Produces more Sustained Body Weight Loss and Improvement of Glycemic Control Compared with VSG in the Diet-Induced Obese Mouse Model. Obes Surg. 2017; 27(9): 2424-33. PubMed Abstract | Publisher Full Text | Free Full Text

31. Coleman DL: Obese and Diabetes: Two Mutant Genes Causing DiabetesObesity Syndromes in Mice. Diabetologia. 1978; 14(3): 141-8. PubMed Abstract | Publisher Full Text

32. Perry RJ, Peng L, Abulizi A, et al.: Mechanism for Leptin's Acute
Insulin-Independent Effect to Reverse Diabetic Ketoacidosis. J Clin Invest. 2017; 127(2): 657-69.

PubMed Abstract | Publisher Full Text | Free Full Text

33. F Fedewa MV, Hathaway ED, Ward-Ritacco CL, et al.: The Effect of Chronic Exercise Training on Leptin: A Systematic Review and Meta-Analysis of Randomized Controlled Trials. Sports Med. 2018; 48(6): 1437-50. PubMed Abstract | Publisher Full Text | F1000 Recommendation

34. Maffei M, Halaas J, Ravussin E, et al:: Leptin Levels in Human and Rodent: Measurement of Plasma Leptin and Ob RNA in Obese and Weight-Reduced Subjects. Nat Med. 1995; 1(11): 1155-61.

PubMed Abstract | Publisher Full Text

35. F Zhang Y, Dallner OS, Nakadai T, et al.: A Noncanonical PPAR $\gamma / \mathbf{R X R} \boldsymbol{\alpha}$-binding Sequence Regulates Leptin Expression in Response to Changes in Adipose Tissue Mass. Proc Natl Acad Sci U S A. 2018; 115(26): E6039-E6047. PubMed Abstract | Publisher Full Text | Free Full Text | F1000 Recommendation

36. Commins SP, Marsh DJ, Thomas SA, et al:: Norepinephrine Is Required for Leptin Effects on Gene Expression in Brown and White Adipose Tissue. Endocrinology. 1999; 140(10): 4772-8. PubMed Abstract | Publisher Full Text

37. Commins SP, Watson PM, Levin N, et al.: Central Leptin Regulates the UCP1 and Ob Genes in Brown and White Adipose Tissue via Different Beta-Adrenoceptor Subtypes. J Biol Chem. 2000; 275(42): 33059-67. PubMed Abstract | Publisher Full Text

38. Swoap SJ, Gutilla MJ, Liles LC, et al:: The Full Expression of Fasting-Induced Torpor Requires Beta 3-adrenergic Receptor Signaling. J Neurosci. 2006; 26(1): 241-5.

PubMed Abstract | Publisher Full Text | Free Full Text

39. Morton GJ, Meek TH, Matsen ME, et al.: Evidence Against HypothalamicPituitary-Adrenal Axis Suppression in the Antidiabetic Action of Leptin. J Clin Invest. 2015; 125(12): 4587-91.

PubMed Abstract | Publisher Full Text | Free Full Text

40. Fukuhara K, Kvetnansky R, Cizza G, et al:: Interrelations Between Sympathoadrenal System and Hypothalamo-Pituitary-Adrenocortical/Thyroid Systems in Rats Exposed to Cold Stress. J Neuroendocrinol. 1996; 8(7): 533-41. PubMed Abstract | Publisher Full Text

41. Gyengesi E, Liu ZW, D'Agostino G, et al.: Corticosterone Regulates Synaptic Input Organization of POMC and NPY/AgRP Neurons in Adult Mice. Endocrinology. 2010; 151(11): 5395-402. PubMed Abstract | Publisher Full Text | Free Full Text

42. F Xu J, Bartolome CL, Low CS, et al.: Genetic Identification of Leptin Neural Circuits in Energy and Glucose Homeostases. Nature. 2018; 556(7702): 505-9. PubMed Abstract | Publisher Full Text | Free Full Text | F1000 Recommendation

43. $\mathrm{F}$ Zhang $\mathrm{Y}$, Kerman IA, Laque A, et al.: Leptin-receptor-expressing Neurons in the Dorsomedial Hypothalamus and Median Preoptic Area Regulate Sympathetic Brown Adipose Tissue Circuits. J Neurosci. 2011; 31(5): 1873-84. PubMed Abstract | Publisher Full Text | Free Full Text | F1000 Recommendation

44. François M, Torres H, Huesing C, et al:: Sympathetic Innervation of the Interscapular Brown Adipose Tissue in Mouse. Ann N Y Acad Sci. 2019; 1454(1) 3-13.

PubMed Abstract | Publisher Full Text | Free Full Text

45. F Bell BB, Harlan SM, Morgan DA, et al.: Differential Contribution of POMC and AgRP Neurons to the Regulation of Regional Autonomic Nerve Activity by Leptin. Mol Metab. 2018; 8: 1-12.

PubMed Abstract | Publisher Full Text | Free Full Text | F1000 Recommendation

46. F Caron A, Dungan Lemko HM, Castorena CM, et al:: POMC Neurons Expressing Leptin Receptors Coordinate Metabolic Responses to Fasting via Suppression of Leptin Levels. eLife. 2018; 7: e33710.

PubMed Abstract | Publisher Full Text | Free Full Text | F1000 Recommendation

47. F Cavalcanti-de-Albuquerque JP, Bober J, Zimmer MR, et al.: Regulation of Substrate Utilization and Adiposity by Agrp Neurons. Nat Commun. 2019; 10(1): 311 .

PubMed Abstract | Publisher Full Text | Free Full Text | F1000 Recommendation

48. Schwartz MW, Woods SC, Porte D, et al:: Central Nervous System Control of Food Intake. Nature. 2000; 404(6778): 661-71. PubMed Abstract | Publisher Full Text

49. Krashes MJ, Lowell BB, Garfield AS: Melanocortin-4 Receptor-Regulated Energy Homeostasis. Nat Neurosci. 2016; 19(2): 206-19. PubMed Abstract | Publisher Full Text | Free Full Tex

50. Yang LK, Tao YX: Biased Signaling at Neural Melanocortin Receptors in Regulation of Energy Homeostasis. Biochim Biophys Acta Mol Basis Dis. 2017; 1863(10 Pt A): 2486-95. PubMed Abstract | Publisher Full Text | Free Full Text

51. $\mathrm{F}$ Beutler LR, Chen Y, Ahn JS, et al:: Dynamics of Gut-Brain Communication Underlying Hunger. Neuron. 2017; 96(2): 461-475.e5. PubMed Abstract | Publisher Full Text | Free Full Text | F1000 Recommendation

52. Nakajima Ki, Cui Z, Li C, et al:: Gs-coupled GPCR Signalling in AgRP Neurons Triggers Sustained Increase in Food Intake. Nat Commun. 2016; 7: 10268 PubMed Abstract | Publisher Full Text | Free Full Text

53. Belgardt BF, Okamura T, Brüning JC: Hormone and Glucose Signalling in POMC and AgRP Neurons. J Physiol. 2009; 587(Pt 22): 5305-14. PubMed Abstract | Publisher Full Text | Free Full Text 
54. F Betley JN, Xu S, Cao ZFH, et al:: Neurons for Hunger and Thirst Transmit a Negative-Valence Teaching Signal. Nature. 2015; 521(7551): 180-5. PubMed Abstract | Publisher Full Text | Free Full Text | F1000 Recommendation

55. $\quad F$ Chen $Y$, Lin $Y C$, Zimmerman CA, et al.: Hunger Neurons Drive Feeding Through a Sustained, Positive Reinforcement Signal. eLife. 2016; 5: e18640. PubMed Abstract | Publisher Full Text | Free Full Text | F1000 Recommendation

56. F Chen Y, Essner RA, Kosar S, et al: Sustained NPY Signaling Enables AgRP Neurons to Drive Feeding. eLife. 2019; 8: e46348.

PubMed Abstract | Publisher Full Text | Free Full Text | F1000 Recommendation

57. Krashes MJ, Shah BP, Koda S, et al:: Rapid Versus Delayed Stimulation of Feeding by the Endogenously Released AgRP Neuron Mediators GABA, NPY, and AgRP. Cell Metab. 2013; 18(4): 588-95. PubMed Abstract | Publisher Full Text | Free Full Text

58. F Thomas MA, Tran V, Ryu V, et al: AgRP Knockdown Blocks Long-Term Appetitive, but Not Consummatory, Feeding Behaviors in Siberian Hamsters. Physiol Behav. 2018; 190: 61-70.

PubMed Abstract | Publisher Full Text | Free Full Text | F1000 Recommendation

59. F Engström Ruud L, Pereira MMA, de Solis AJ, et al:: NPY Mediates the Rapid Feeding and Glucose Metabolism Regulatory Functions of AgRP Neurons. Nat Commun. 2020; 11(1): 829 .

PubMed Abstract | Publisher Full Text | Free Full Text | F1000 Recommendation

60. F Krashes MJ, Koda S, Ye CP, et al:: Rapid, Reversible Activation of AgRP Neurons Drives Feeding Behavior in Mice. J Clin Invest. 2011: 121(4): 1424-8. PubMed Abstract | Publisher Full Text | Free Full Text | F1000 Recommendation

61. F Aponte Y, Atasoy D, Sternson SM: AGRP Neurons Are Sufficient to Orchestrate Feeding Behavior Rapidly and Without Training. Nat Neurosci. 2011; 14(3): 351-5. PubMed Abstract | Publisher Full Text | Free Full Text | F1000 Recommendation

62. F Patkar PP, Hao Z, Mumphrey MB, et al:: Unlike Calorie Restriction, Roux-en$Y$ Gastric Bypass Surgery Does Not Increase Hypothalamic AgRP and NPY in Mice on a High-Fat Diet. Int J Obes (Lond). 2019; 43(11): 2143-50. PubMed Abstract | Publisher Full Text | Free Full Text | F1000 Recommendation

63. Hatoum IJ, Stylopoulos N, Vanhoose AM, et al:: Melanocortin-4 Receptor Signaling Is Required for Weight Loss after Gastric Bypass Surgery. J Clin Endocrinol Metab. 2012; 97(6): E1023-E1031.

PubMed Abstract | Publisher Full Text | Free Full Text

64. Hao Z, Münzberg H, Rezai-Zadeh K, et al: Leptin Deficient Ob/Ob Mice and DietInduced Obese Mice Responded Differently to Roux-en-Y Bypass Surgery. Int J Obes (Lond). 2015; 39(5): 798-805.

PubMed Abstract | Publisher Full Text | Free Full Text

65. Mul JD, Begg DP, Alsters SIM, et al.: Effect of Vertical Sleeve Gastrectomy in Melanocortin Receptor 4-deficient Rats. Am J Physiol Endocrinol Metab. 2012; 303(1): E103-E110.

PubMed Abstract | Publisher Full Text | Free Full Text

66. Hagan MM, Rushing PA, Schwartz MW, et al:: Role of the CNS Melanocortin System in the Response to Overfeeding. J Neurosci. 1999; 19(6): 2362-7. PubMed Abstract | Publisher Full Text | Free Full Text

67. White CL, Purpera MN, Ballard K, et al.: Decreased Food Intake Following Overfeeding Involves Leptin-Dependent and Leptin-Independent Mechanisms. Physiol Behav. 2010; 100(4): 408-16.

PubMed Abstract | Publisher Full Text | Free Full Text

68. F Balthasar N, Dalgaard LT, Lee CE, et al:: Divergence of Melanocortin Pathways in the Control of Food Intake and Energy Expenditure. Cell. 2005; 123(3): 493-505.

PubMed Abstract | Publisher Full Text | F1000 Recommendation

69. $\mathrm{F}$ Bates SH, Stearns WH, Dundon TA, et al.: STAT3 Signalling Is Required for Leptin Regulation of Energy Balance but Not Reproduction. Nature. 2003; 421(6925): 856-9.

PubMed Abstract | Publisher Full Text | F1000 Recommendation

70. Krude H, Biebermann H, Luck W, et al:: Severe Early-Onset Obesity, Adrenal Insufficiency and Red Hair Pigmentation Caused by POMC Mutations in Humans. Nat Genet. 1998; 19(2): 155-7.

PubMed Abstract | Publisher Full Text

71. F Clément K, Biebermann H, Farooqi IS, et al.: MC4R Agonism Promotes Durable Weight Loss in Patients With Leptin Receptor Deficiency. Nat Med. 2018; 24(5): 551-5.

PubMed Abstract | Publisher Full Text | F1000 Recommendation

72. Chen $\mathrm{M}$, Shrestha $\mathrm{YB}$, Podyma $\mathrm{B}$, et al: $\mathrm{G}_{\mathrm{s}} a$ deficiency in the dorsomedial hypothalamus underlies obesity associated with $\mathrm{G}_{\mathrm{s}} \boldsymbol{a}$ mutations. $J$ Clin Invest. 2017: 127(2): 500-10.

PubMed Abstract | Publisher Full Text | Free Full Text

73. F Balthasar N, Coppari R, McMinn J, et al.: Leptin Receptor Signaling in POMC Neurons Is Required for Normal Body Weight Homeostasis. Neuron. 2004; 42(6): 983-91.

PubMed Abstract | Publisher Full Text | F1000 Recommendation

74. van de Wall E, Leshan R, Xu AW, et al:: Collective and Individual Functions of Leptin Receptor Modulated Neurons Controlling Metabolism and Ingestion. Endocrinology. 2008; 149(4): 1773-85.

PubMed Abstract | Publisher Full Text | Free Full Text

75. Flak JN, Myers MG: Minireview: CNS Mechanisms of Leptin Action. Mol Endocrinol. 2016; 30(1): 3-12.

PubMed Abstract | Publisher Full Text | Free Full Text
76. F Li C, Navarrete J, Liang-Guallpa J, et al.: Defined Paraventricula Hypothalamic Populations Exhibit Differential Responses to Food Contingent on Caloric State. Cell Metab. 2019; 29(3): 681-694.e5.

PubMed Abstract | Publisher Full Text | Free Full Text | F1000 Recommendation

77. F Fischer AW, Cannon B, Nedergaard J: Leptin: Is It Thermogenic? Endocr Rev. 2020; 41(2): 232-260.

PubMed Abstract | Publisher Full Text | Free Full Text | F1000 Recommendation

78. Rahmouni K, Morgan DA: Hypothalamic Arcuate Nucleus Mediates the Sympathetic and Arterial Pressure Responses to Leptin. Hypertension. 2007; 49(3): 647-52.

PubMed Abstract | Publisher Full Text

79. Morrison SF: Activation of 5-HT Receptors in Raphe Pallidus Inhibits LeptinEvoked Increases in Brown Adipose Tissue Thermogenesis. Am J Physiol Regul Integr Comp Physiol. 2004; 286(5): R832-7.

PubMed Abstract | Publisher Full Text

80. Döring H, Schwarzer K, Nuesslein-Hildesheim B, et al.: Leptin Selectively Increases Energy Expenditure of Food-Restricted Lean Mice. Int J Obes Relat Metab Disord. 1998; 22(2): 83-8.

PubMed Abstract | Publisher Full Text

81. Yu S, Cheng H, François M, et al:: Preoptic Leptin Signaling Modulates Energy Balance Independent of Body Temperature Regulation. eL ife. 2018; 7: e33505. PubMed Abstract | Publisher Full Text | Free Full Text

82. Galgani JE, Greenway FL, Caglayan S, et al.: Leptin Replacement Prevents Weight Loss-Induced Metabolic Adaptation in Congenital Leptin-Deficient Patients. J Clin Endocrinol Metab. 2010; 95(2): 851-5. PubMed Abstract | Publisher Full Text | Free Full Text

83. Davis TR, Mayer J: Imperfect Homeothermia in the Hereditary ObeseHyperglycemic Syndrome of Mice. Am J Physiol. 1954; 177(2): 222-6. PubMed Abstract | Publisher Full Text

84. Harris RB, Kasser TR, Martin RJ: Dynamics of Recovery of Body Composition After Overfeeding, Food Restriction or Starvation of Mature Female Rats. J Nutr. 1986; 116(12): 2536-46. PubMed Abstract | Publisher Full Text

85. Rezai-Zadeh K, Yu S, Jiang Y, et al.: Leptin Receptor Neurons in the Dorsomedial Hypothalamus Are Key Regulators of Energy Expenditure and Body Weight, but Not Food Intake. Mol Metab. 2014; 3(7): 681-93. PubMed Abstract | Publisher Full Text | Free Full Text

86. F Ukropec J, Anunciado RVP, Ravussin Y, et al:: Leptin Is Required for Uncoupling Protein-1-Independent Thermogenesis during Cold Stress. Endocrinology. 2006; 147(5): 2468-80.

PubMed Abstract | Publisher Full Text | F1000 Recommendation

87. F Madden CJ, Morrison SF: Central nervous system circuits that control body temperature. Neurosci Lett. 2019; 696: 225-32.

PubMed Abstract | Publisher Full Text | Free Full Text | F1000 Recommendation

88. F de Git KCG, den Outer JA, Wolterink-Donselaar IG, et al:: Rats that are predisposed to excessive obesity show reduced (leptin-induced) thermoregulation even in the preobese state. Physiol Rep. 2019; 7(14): e14102. PubMed Abstract | Publisher Full Text | Free Full Text | F1000 Recommendation

89. Yu S, Qualls-Creekmore E, Rezai-Zadeh K, et al.: Glutamatergic Preoptic Area Neurons That Express Leptin Receptors Drive Temperature-Dependent Body Weight Homeostasis. J Neurosci. 2016; 36(18): 5034-46. PubMed Abstract | Publisher Full Text | Free Full Text

90. Nakamura K, Matsumura K, Kaneko T, et al.: The Rostral Raphe Pallidus Nucleus Mediates Pyrogenic Transmission from the Preoptic Area. J Neurosci. 2002; 22(11): 4600-10.

PubMed Abstract | Publisher Full Text | Free Full Text

91. F Tan CL, Cooke EK, Leib DE, et al.: Warm-Sensitive Neurons that Control Body Temperature. Cell. 2016; 167(1): 47-59.e15. PubMed Abstract | Publisher Full Text | Free Full Text | F1000 Recommendation

92. $\mathrm{F}$ Moffitt JR, Bambah-Mukku D, Eichhorn SW, et al:: Molecular, spatial, and functional single-cell profiling of the hypothalamic preoptic region. Science. 2018; 362(6416): eaau5324.

PubMed Abstract | Publisher Full Text | Free Full Text | F1000 Recommendation

93. Cao WH, Fan W, Morrison SF: Medullary pathways mediating specific sympathetic responses to activation of dorsomedial hypothalamus. Neuroscience. 2004; 126(1): 229-40.

PubMed Abstract | Publisher Full Text

94. F Nakamura $\mathrm{Y}$, Nakamura K, Matsumura K, et al.: Direct pyrogenic input from prostaglandin EP3 receptor-expressing preoptic neurons to the dorsomedial hypothalamus. Eur J Neurosci. 2005; 22(12): 3137-46.

PubMed Abstract | Publisher Full Text | Free Full Text | F1000 Recommendation

95. Yoshida K, Li X, Cano G, et al:: Parallel preoptic pathways for thermoregulation. J Neurosci. 2009; 29(38): 11954-64.

PubMed Abstract | Publisher Full Text | Free Full Text

96. Kaiyala KJ, Ogimoto $\mathrm{K}$, Nelson JT, et al:: Leptin signaling is required for adaptive changes in food intake, but not energy expenditure, in response to different thermal conditions. PLoS One. 2015; 10(3): e0119391. PubMed Abstract | Publisher Full Text | Free Full Text

97. Yu S, François M, Huesing C, et al:: The Hypothalamic Preoptic Area and Body Weight Control. Neuroendocrinology. 2018; 106(2): 187-94.

PubMed Abstract | Publisher Full Text | Free Full Text 


\section{Open Peer Review}

\section{Current Peer Review Status:}

\section{Editorial Note on the Review Process}

Faculty Reviews are review articles written by the prestigious Members of Faculty Opinions. The articles are commissioned and peer reviewed before publication to ensure that the final, published version is comprehensive and accessible. The reviewers who approved the final version are listed with their names and affiliations.

\section{The reviewers who approved this article are:}

\section{Version 1}

\section{Carol F Elias}

Department of Molecular \& Integrative Physiology, University of Michigan, Ann Arbor, MI, USA Competing Interests: No competing interests were disclosed.

\section{Greg M Anderson}

Centre for Neuroendocrinology and Department of Anatomy, University of Otago, Dunedin, New Zealand

Competing Interests: No competing interests were disclosed.

The benefits of publishing with F1000Research:

- Your article is published within days, with no editorial bias

- You can publish traditional articles, null/negative results, case reports, data notes and more

- The peer review process is transparent and collaborative

- Your article is indexed in PubMed after passing peer review

- Dedicated customer support at every stage

For pre-submission enquiries, contact research@f1000.com 